\title{
Selective Reduction of Trigonellyl Group to the Corresponding Dihydropyridine in the Presence of Disulfide Group
}

\author{
Ho-Joon Park, Young-Gyun Shin, Sang-Hoo Park, Jiaxaing Wu, Nicholas Bodor, ${ }^{\dagger}$ and Sung-Hwa Yoon

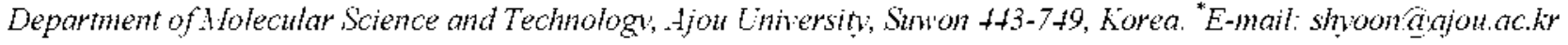 \\ Center for Drig Discovery, Lniversity of Florida, Gainesville, FL 32611, LSA \\ Received October 22, 2007
}

Key Words : Blood brain barnier. Trigonellỵl group. Disulfide bond. 1-Benzyl-1,2-dilỵdroisonicotinamide

For many years. there has been considerable interest in the synthetic method. utility, and biological activity of various dilydropyridines. ${ }^{3}$ In recent years. based on the redox system, which is analogous to the endogenous NADH-NAD system. we developed a chemical delivery system (CDS), using a dilydropyridine-pyndunum ion redox system for the specific delivery and sustained release of drug in the brain. ${ }^{2}$ In this CDS system, the biologically active compound linked to a lipoidal dihydropyndme carrier can crosses the BBB and is then oxidized to the pyridinium ion form in the brain. which is locked and retained in the brain because the increased hydrophilicity hinders BBB permeability (Figure 1). ${ }^{3}$

For the synthesis of CDS, the dihydropyndine carrier is generally untroduced to drugs by reduction of the corresponding $\mathrm{N}$-methylpyndinim ion (trigonellyl group) with sodium dithionite. ${ }^{+5}$ However. when we attempted to deliver the peptide drugs containing the disulfide bond. such as Somatostatin, to the brain. we faced unexpected difficulty in introducing the dihydropyridine carrier to the peptide drugs. since the disulfide bond in the peptide structure that fixes its tertiary structure is prone to reduce into the corresponding thiol under general reduction conditions. Although the reduction of the $\mathrm{N}$-methyl-pyridinium salt into $\mathrm{N}$-methyl1,4-dilydropyridine has been well described, interestingly. there are no reports on the selective reduction of the $\mathrm{N}$ methylpyridinium ion into the corresponding dihydropyridine without cleavage of the disulfide bond. In order to achieve the brain-targeted delivery of peptides that contain the disulfide bond in their structure, we proposed to find the selective reducing agent and the reaction condition that only reduces the trigonellyl group in the presence of the disulfide group by investigatung various reducing agents. We chose 1benzyl-1,2-dilhydroisonicot-anide $\mathbf{5}$ as the selective reducing agent for this purpose.

For selective reduction of the trigonellyl group in the<smiles>C[n+]1cccc(C(=O)NC(=O)c2ccccc2)c1</smiles><smiles>C=C1OC(=O)C1=C</smiles><smiles>CN1C=CCC(C(=O)NCc2ccccc2)=C1</smiles>

Figure 1. Brain targeting CDS approach by the dihy dropyndinepyridinium ion redox system. presence of the disulfide group. trigonellyl-cystme ethyl ester ( $\mathrm{Trg}-\mathrm{Cys}-\mathrm{OEt})_{2} \mathbf{2}$ was chosen as a model compound because this compound has two trigonellyl groups and a symmetrical alkyl disulfide bond in its structure. In order to synthesize (Trg-Cys-OEt)2 2, L-cystine diethyl ester dihydrochlonde purchased from Aldrich Company was used as the starting material. After the coupling reaction of the Lcystme dietlyl ester dihydrochlonde with nicotinic acid. which was accelerated with disopropylcarbodiumide and lhydroxybenzo-triazole. ${ }^{6} \mathrm{~N}$-methylation of the resulting
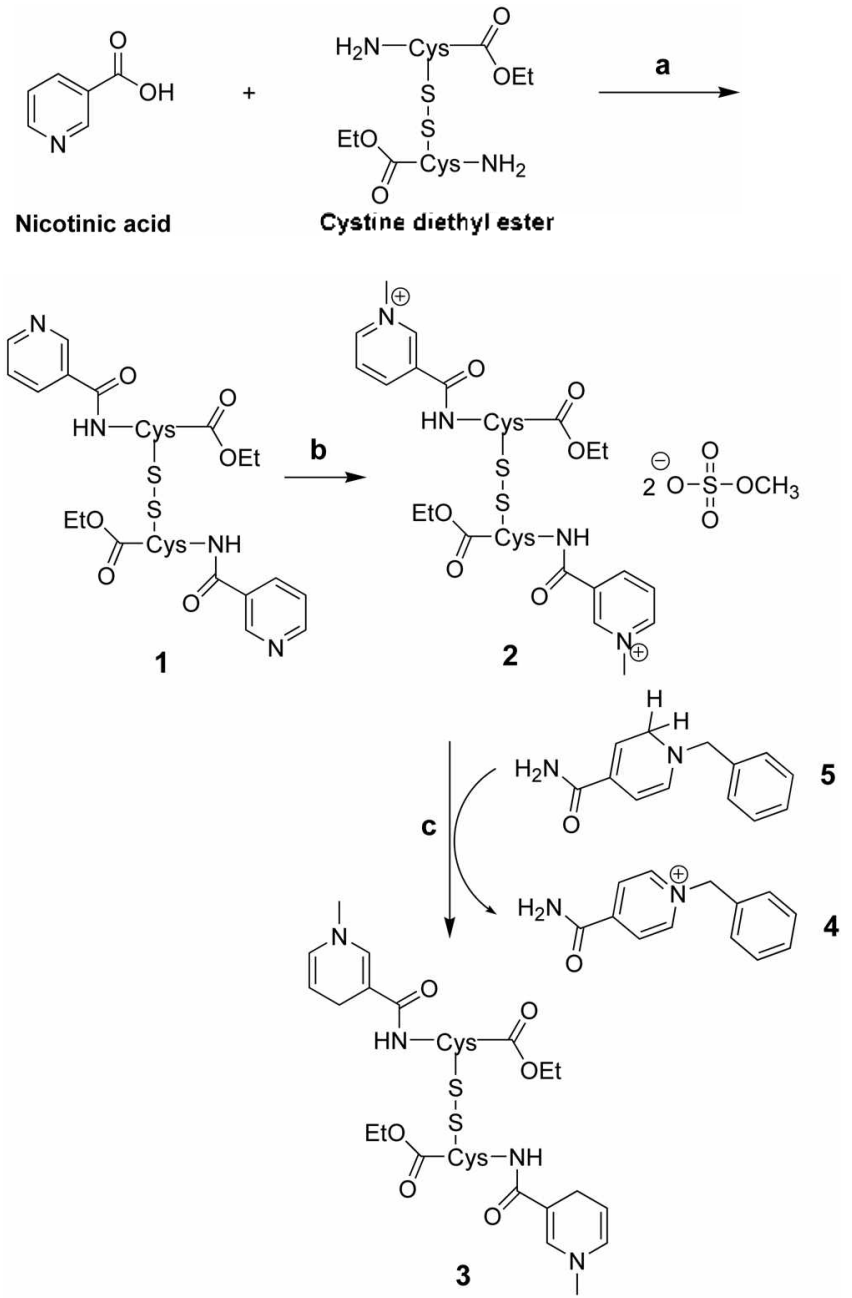

Scheme 1. (a) DMA, DIC, HOBt, 2 hours, r.t. (b) dimethylsulfate, $\mathrm{CHCl}_{3}, 12$ hours, r.t.; (c) methanol, $-24^{\circ} \mathrm{C}, 20 \mathrm{~min}$. 


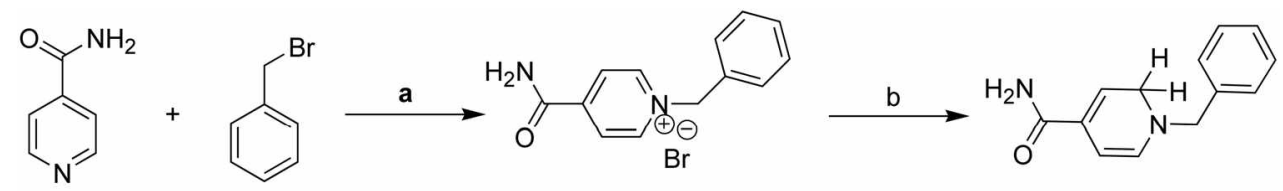

Isonicotamide Benzyl bromide

4

5

Scheme 2. (a) $\mathrm{CH}_{3} \mathrm{CN}$, reflus, 3 hours: (b) $\mathrm{NaBH}_{4}, \mathrm{NaOH},-24^{\circ} \mathrm{C}, 1$ hour.

nicotinyl cystine ethyl ester 1 was performed with dimethylsulfate to afford the desired $\mathrm{N}$-methylpyridinium compound $2^{7}$ (Schene 1).

Selective reduction of trigonellyl group in compound 2 was first attempted with sodium dithionite since it has been reported that the dithionite reduction of pyridinium salts results in the preferential formation of the 1.4-dihydropyridine over the other ( 1.2 or 1.3 ) possible structural isomers. ${ }^{7.9}$ However, our attempts with various sodium dithionite conditions always reduced not only the desired pyridinium moiety, but also the disulfide bridge. This result was easily confirmed by the appearance of the unique thiol peak from the reduction of the disulfide bridge at $2523 \mathrm{~cm}^{-1}$ in the IRspectrum as well as the characteristic $\mathrm{C}-4$ dihydropyridine peak at $\delta 3.4$ and $\mathrm{N}-\mathrm{CH}_{3}$ peak at $\delta 2.9$ in the ${ }^{1} \mathrm{H}-\mathrm{NMR}$ spectra from the reduction of the trigonellyl group.

Other reducing agents. such as triphenyl-phosphine/ $\mathrm{H}_{2} \mathrm{O}{ }^{11}{ }^{11}$ lithium tri-tert-butoxy aluminohydride (LTBA). ${ }^{11}$ lithium aluminum hydride, ${ }^{12}$ lithium trimethosy aluminohydride (LTMA). ${ }^{13}$ lithium aluminum hydride. ${ }^{14}$ lithium triethylborohydride. ${ }^{15}$ sodium borohydride. ${ }^{16}$ and potassium triisopropoxy-borohydride. ${ }^{17}$ were also attempted. However. these reagents reduced the disulfide linkage into the corresponding thiol, as previously reported.

We then chose 1-benzyl-1.2-dihydroisonicotinamide 5 as a selective reducing agent for the above reaction since 1benzyl-1,2-dihydroiso-nicotinamide $\mathbf{5}$ was known as a mild reducing agent. which could transfer its hydrides only to trigonellyl group without breaking the disulfide bond. The synthesis of 1-benzyl-1.2-dihydroisonicotinamide 5 was accomplished by the coupling reaction of isonicotinamide with benzylbromide in acetonitrile in ambient temperature followed by the reduction of the resulting 1-benzyl-1.2dihy'droisonicotinamide 4 with sodium borohydride at -24 ${ }^{\circ} \mathrm{C}$. as shown in Scheme 2.

When (Trg-Cys-OEt) 2 was reduced with 1-benzyl-1,2dihydroisonicotinamide $\mathbf{5}$ in methanol under a nitrogen atmosphere. the corresponding dihydro-trigonellyl-cystine ethyl ester (Dhtrg-Cys-OEt) $\mathbf{3}$ was successfully obtained. This reaction was carefully performed in darkness under a nitrogen atmosphere because compound 3 was very sensitive to light humidity. and oxygen.

The formation of compound 3 was confirmed with electrospray ionization mass spectrometry (ESI-MS). As shown in Figure 2. before the reaction. we observed the molecular ion peaks of compound 2 at $\mathrm{m} / \mathrm{z}=535$ along with that of other fragment ions such as $[\mathrm{M}+2 \mathrm{H}]^{\hat{+}} / 2$ ion and $[\mathrm{M}+\mathrm{H}]^{+}$ methyl sulfate ion at $\mathrm{m} / \mathrm{z}=268$ and 647 . respectively (spec-
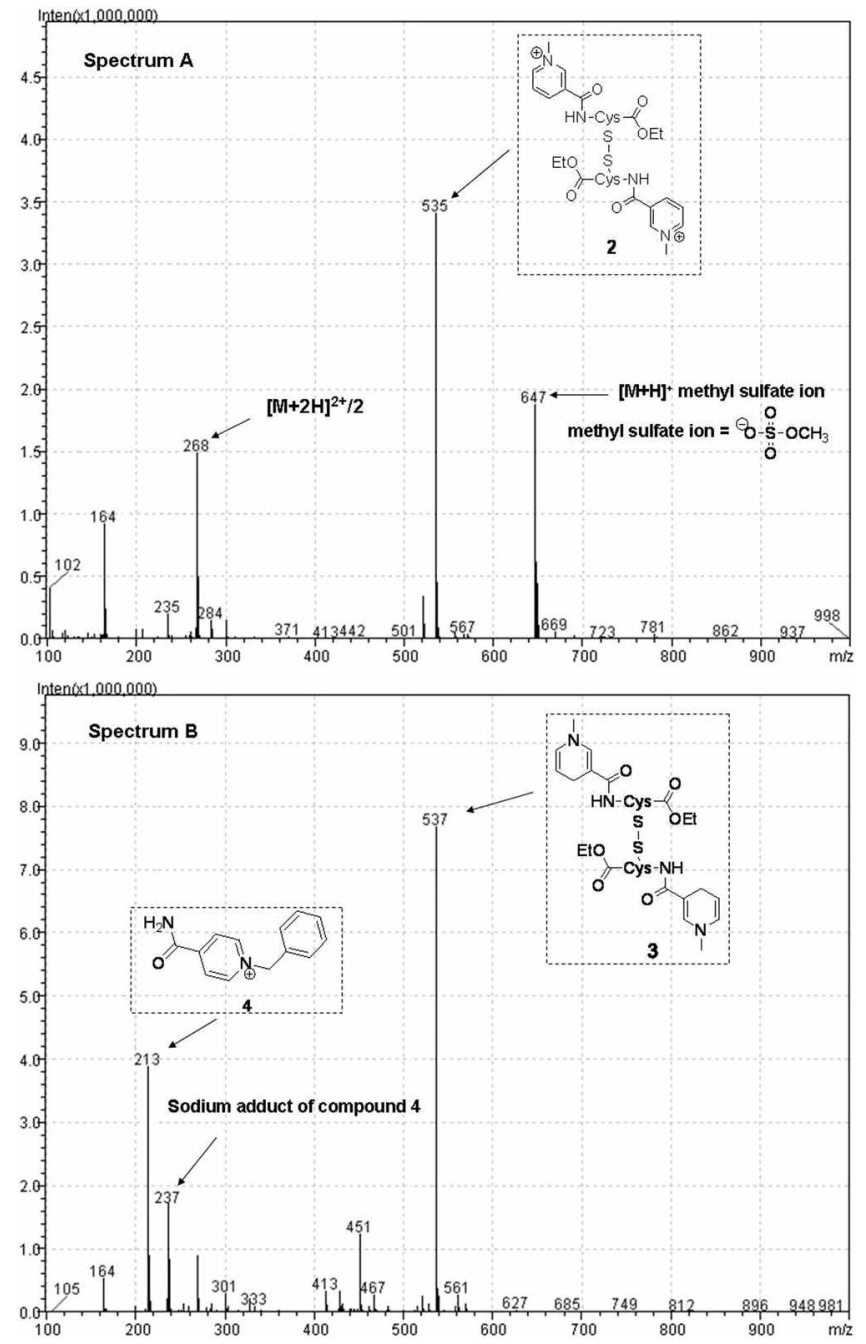

Figure 2. ESI-MS spectra of (Trg-Cys-OEt) 2 (Spectrum A) and (Dhtrg-Cys-OEt) 3 (Spectrum B).

trum A). After the reaction. we obtained two distinctive molecular ion peaks at $\mathrm{m} / \mathrm{z}=213$ and 537, which are consistent with the molecular weights of 1-benzyl-1.2-dihydroisonicotinamide 4 and dily'drotrigonellyl-cystine ethyl ester (Dhtrg-Cys-OEt) 3 . respectively (spectrum B).

These ESI-MS spectra clearly indicate that there was no reduction of the disulfide bond with 1-benzyl-1.2-dihydroisonicotinamide 5 . This is because the molecular ion peak of the thiol compound in which both the trigonellyl group and the disulfide bond were reduced was not observed at $\mathrm{m} / \mathrm{z}=$ 269 in spectrum B. In addition. the peak of the typical dihydropyridine protons and the $\mathrm{N}-\mathrm{CH}_{3}$ peak from the product appeared at $3.4 \mathrm{ppm}$ and $2.9 \mathrm{ppm}$ in ${ }^{1} \mathrm{H}-\mathrm{NMR}$ 
spectroscopy without the appearance of the thiol peak at $2523 \mathrm{~cm}^{-1}$ in IR spectrum.

In conclusion. we found that 1-benzyl-1.2-dihydroisonicotamide $\mathbf{5}$ is a useful reducing agent for the selective reduction of the trigonellyl group without cleavage of a disulfide bond.

\section{Experimental Section}

Instruments. Melting points were determined on a FisherJohus melting point apparatus. ${ }^{1} \mathrm{H}-\mathrm{NMR}$ and ${ }^{13} \mathrm{C}-\mathrm{NMR}$ spectra were recorded on a Verian-Germini spectrameter at $400 \mathrm{MHz}$ and $100 \mathrm{MHz}$. Chenical Shifts were given in relative tetrantethy lsilane. Infrared spectra were recorded on a Nicolet FT-IR 550 spectrameter. Mass spectra were performed by Shinadzu LCMS-2010EV spectrameter. Japan. Colunu chromatography was done by using Merck silica gel 60 (230-400 mesh).

Diethyl 3,3'-disulfanediyl-bis-2-nicotinamido-propanoate (1). To a solution of nicotinic acid $(3.72 \mathrm{~g} .32 .0 \mathrm{~mm}$ ol) in DMA $(40.0 \mathrm{~mL})$ was added l-hydroxybenzotriazole $(4.09 \mathrm{~g}$. $30.2 \mathrm{mmol}$ ) and 1,3-diisopropylcarbodiinide (3.31 g, 30.2 mmol) dropwise under a nitrogen atmosphere. The resulting suspension was allowed to react for two hours until it turned in the clear solution. To this clear solution was added the solution of L-Cystine diethyl ester dilhydrochloric acid dissolved in DMA (10.0 mL) and later neutralized with triethylamine $(3.05$ g. $30.2 \mathrm{mmol})$. After the reaction mixture was stirred for two hours, the white precipitate was filtered. The filtrate was partitioned with methy lene chloride and water. The organic layer was washed with water $(4 \times$ $50.0 \mathrm{~mL}$ ) and saturated aqueous $\mathrm{NaHCO}_{3}$ solution. It was transferred to aqueous layer by using $5 \%$ citric acid solution. After the aqueous layer was neutralized by saturated aqueous $\mathrm{NaHCO}_{3}$ solution. it was extracted by ethyl acetate $(3 \times 50.0 \mathrm{~mL})$. The combined organic layer was dried over $\mathrm{MgSO}_{4}$, filtered. and concentrated. The crude product was purified by silica gel column chromatography to give a white solid (5.01 g. 81.6\%): mp $188-190^{\circ} \mathrm{C}$ : IR (KBr) 3157.2, 2299.3,1741.0,1669.2 $\mathrm{cm}^{-1}:{ }^{1} \mathrm{H} \mathrm{NMR}\left(\mathrm{CDCl}_{\hat{j}}\right) \delta$ 9.04-9.05 (1H, d. $J=2.0 \mathrm{~Hz}) .8 .72-8.74(\mathrm{lH} . \mathrm{d} . J=4.5 \mathrm{~Hz})$. 7.33-7.37 (1H. q. $J=1.5 \mathrm{~Hz}$ and $6.3 \mathrm{~Hz}) \cdot 7.19-7.21(1 \mathrm{H}, \mathrm{d} . J$ $=7.3 \mathrm{~Hz}) .5 .05(1 \mathrm{H}, \mathrm{m}), 4.24-4.27(2 \mathrm{H}, \mathrm{q} . J=4.4 \mathrm{~Hz}$ and $11.7 \mathrm{~Hz}$ ). $3.35-3.37(2 \mathrm{H} . \mathrm{d} . J=7.0 \mathrm{~Hz}$ ). 1.29-1.31 (3H. t. $J=$ $7.1 \mathrm{~Hz}):{ }^{13} \mathrm{C}$ NMR $\left(\mathrm{CDCl}_{3}\right) \& 170.10 .165 .45,152.65$. 148.34. 135.10. 129.27, 123.42, 77.61. 77.08. 76.42, 62.33. 52.55 .40 .55 .14 .16 : ESI-MS $m z 507.01[\mathrm{M}+\mathrm{H}]^{+}$.

3,3'-(3,3'-Disulfanediyl-bis-1-ethoxy-1-oxopro-pane-3,2diyl)-bis-azanediyl-bis-oxomethylene-bis-1-methylpyridinium (2). To a solution of N- $\alpha \alpha$-nicotinic cystine diethyl ester $(4.95 \mathrm{~g}, 9.79 \mathrm{~mm}$ ol $)$ in $\mathrm{CHCl}_{\hat{j}}(100 \mathrm{~mL})$ was added dimethylsulfate $(3.08 \mathrm{~g}, 24.5 \mathrm{~nm}$ ol) dropwise under a nitrogen atmosphere. After the reaction mixture was stirred for 12 hours. it was concentrated until the final volume of the mixture was about $10.0 \mathrm{~mL}$. Later. ether $(50.0 \mathrm{~mL})$ was added to the concentrate and stirred for $10 \mathrm{~min}$. The resulting precipitate was decanted with ether several times and dried to give a hydroscopic white solid (7.06 g. $95.0 \%$ ): $\operatorname{mp} 70.2{ }^{\circ} \mathrm{C}$; IR (neat) 3368.4. 2988.6. 2254.8. 1746.8. $1642.7 \mathrm{~cm}^{-1}$. ${ }^{1} \mathrm{H}$ NMR $\left(\mathrm{CDCl}_{3}+\mathrm{DMSO}-d_{6}\right) \delta 8.93-8.95(1 \mathrm{H}$, d. $J=7.6 \mathrm{~Hz}) .8 .76-8.77(1 \mathrm{H}, \mathrm{d}, J=6.0 \mathrm{~Hz}) .8 .54-8.56(\mathrm{lH}$, d. $J=8.0 \mathrm{~Hz}) .7 .76-7.79(\mathrm{lH} . \mathrm{t} . J=14.0 \mathrm{~Hz}), 4.49-4.54(\mathrm{lH}$. $\mathrm{m}), 4.19(3 \mathrm{H}, \mathrm{s}), 3.80-3.86(2 \mathrm{H}, \mathrm{q} . J=6.8 \mathrm{~Hz}$ and $21.2 \mathrm{~Hz})$, $3.29(3 \mathrm{H}, \mathrm{s}), 0.90-0.94(3 \mathrm{H}, \mathrm{t}, J=16.0 \mathrm{~Hz}):{ }^{13} \mathrm{C} \mathrm{NMR}$ $\left(\mathrm{CDCl}_{3}+\mathrm{DMSO}-d_{6}\right) \quad \delta \quad 168.80,160.75 .146 .75,144.34$. $143.10,132.77 .127 .22,61.14,53.62 .52 .13,48.21,13.56$ : ESI-MS $m z 535.66[\mathrm{M}+\mathrm{H}]^{+}$

Diethyl-3,3'-disulfanediyl-bis-2(1-methyl-1,t-dli-hydıopyridine-3-carboxamido)-propanoate (3). To a stirred solution of 1-benzyl-1,2-dihydroisonicotinamide $(0.26 \mathrm{~g}$. $1.20 \mathrm{mmol}$ ) was added (Trg-Cy s-OEt) $2(0.50 \mathrm{~g} .0 .65 \mathrm{mmol})$ in methanol $(10.0 \mathrm{~mL})$ at $-24^{\circ} \mathrm{C}$ in the dark under a nitrogen atmosphere. After the resulting misture was stirred for 20 minutes in the dark. the solvent was removed. The residue was diluted with methylene chloride $(30.0 \mathrm{~mL})$. The organic layer was washed with water $(10.0 \mathrm{~mL})$. dried over $\mathrm{MgSO}_{4}$, and concentrated to give the crude product as orangecolored oil. Because of instability of the product, the crude product was used for IR. NMR and mass spectrometric investigations without further purification. IR (neat) 3346.7 . $2254.8,2132.2,1714.1 \mathrm{~cm}^{-1}$. ${ }^{1} \mathrm{H}$ NMR (CDCl$\left.+\mathrm{CHMO}_{3}+\mathrm{D}_{6}\right)$ $\delta 9.61-9.59(\mathrm{lH} . \mathrm{d}, J=8.0 \mathrm{~Hz}$ ), $9.33-9.35$ (1H. m). 9.09-9.11 (lH. d. $J=8.0 \mathrm{~Hz}), 8.85-8.87(\mathrm{lH}, \mathrm{d}, J=8.0 \mathrm{~Hz}), 8.40-8.4 \mathrm{l}$ (lH. m), 8.22-8.25 (lH. m), $7.41-7.52$ (lH. m), 4.80-4.84 (lH. m). $4.39(3 \mathrm{H}, \mathrm{s}), 4.11-4.17(2 \mathrm{H} . \mathrm{t} . J=24.0 \mathrm{~Hz}) .3 .33$ (3H. s) $3.30-3.45(2 \mathrm{H} . \mathrm{m}) 3.12-3.16(2 \mathrm{H} . \mathrm{m})$. $1.18-1.22(3 \mathrm{H}$, t. $J=16.0 \mathrm{~Hz}) ;{ }^{12} \mathrm{C}$ NMR $\left(\mathrm{CDCl}_{3}+\mathrm{DMSO}-d_{6}\right) \delta 171.08$. 163.49, 148.67. 146.70. 144.40, 134.87, 130.97. 130.61, $130.24,129.02 .127 .59,63.17 .55 .25 .54 .10 .40 .80,14.65$. ESI-MS $m z 537.95[\mathrm{M}+\mathrm{H}]^{+}$

1-Benzyl-4-carbamoylpyridinium bromide (4). To a suspension of isonicotinamide $(3.02 \mathrm{~g} .24 .5 \mathrm{mmol}$ ) in acetonitrile $(100 \mathrm{~mL})$ was added benzyl bromide $(3.42 \mathrm{~mL}, 39.3$ numol) under a nitrogen atmosphere. After the mixture was refluxed for three hours at $70^{\circ} \mathrm{C}$, the white precipitate was filtered. In order to remove the unreacted starting material. the precipitate was re-dissolved in acetonitrile $(50.0 \mathrm{~mL}$ ). stirred for 30 minutes. and then filtered again to give a product as a white powder. $(5.10 \mathrm{~g} .97 .6 \%): \mathrm{mp}>280^{\circ} \mathrm{C}$ (dec.); IR (KBr) 3356.2, $1669.7 \mathrm{~cm}^{-1} ;{ }^{1} \mathrm{H}$ NMR (DMSO- $d_{b}$ ) $\delta 9.40-9.42(2 \mathrm{H}, \mathrm{d}, J=8.0 \mathrm{~Hz}), 8.44-8.46(2 \mathrm{H}, \mathrm{d} . J=8.0$ $\mathrm{Hz}), 7.64(2 \mathrm{H}, \mathrm{m}), 7.56-7.57(2 \mathrm{H}, \mathrm{m}), 7.42-7.43(3 \mathrm{H}, \mathrm{m})$ $5.94(2 \mathrm{H}, \mathrm{s}):{ }^{13} \mathrm{C}$ NMR (DMSO- $\left.d_{b}\right) \quad \delta$ 163.27. 148.54. $145.73,134.11,129.45 .129 .24,128.95 .126 .30,113.78$, 63.36: ESI-MS $m \geq 214.01[\mathrm{M}+\mathrm{H}]^{-}$

1-Benzyl-1,2-dihydropyridine-4-carboxamide (5). To a suspension of 1-benzyl-4-carbamoỵl-pyrridinium bromide $(5.02 \mathrm{~g} .16 .3 \mathrm{mmol})$ in methanol $(30.0 \mathrm{~mL})$ was added the solution of sodium hydroxide $(1.02 \mathrm{~g} .25 .0 \mathrm{mmol})$ in water $(20.0 \mathrm{~mL})$ followed by $\mathrm{NaBH}_{4}(309 \mathrm{mg}, 8.17 \mathrm{mmol})$ in one portion at $-24{ }^{\circ} \mathrm{C}$ under a nitrogen atmosphere. After the reaction mixture was stirred for 1 hour at $-24^{\circ} \mathrm{C}$. the precipitate was filtered. washed with the cold mixture of water $(100 \mathrm{~mL})$ and methanol $(10.0 \mathrm{~mL})$ followed by ether 
$(50.0 \mathrm{~mL})$. After the solid was dried, it was stored in refrigerator before use under a nitrogen atmosphere. The product was white solid. $(4.51 \mathrm{~g}, 90.0 \%)$ : $\mathrm{mp}>290^{\circ} \mathrm{C}$ (dec.): IR (KBr) 3396.4, 3191.4. $1638.7 \mathrm{~cm}^{-1}:{ }^{1} \mathrm{H}$ NMR (DMSO- $\left.d_{6}\right) \delta 7.24-7.35(5 \mathrm{H}, \mathrm{ml}), 6.32-6.34(\mathrm{lH} . \mathrm{d}, J=8.0$ $\mathrm{Hz}), 5.66-5.67(\mathrm{lH}, \mathrm{bs}), 4.90-4.92(\mathrm{lH} . \mathrm{d}, J=9.2 \mathrm{~Hz}), 4.02$ $(2 \mathrm{H}, \mathrm{s}), 3.78-3.79(2 \mathrm{H}, \mathrm{d} . J=4.4 \mathrm{~Hz}) ;{ }^{13} \mathrm{C}$ NMR (DMSO- $\left.d_{6}\right)$ $\delta 166.76,139.05 .136 .78 .131 .78,128.26 .127 .87,127.11$. $114.04,91.92,57.52,46.93$ : ESI-MS $m: 215.01[\mathrm{M}+\mathrm{H}]^{-}$.

Acknowledgment. This study was supported by the Post Brain Korea 21 progran.

\section{References}

1. (a) Stout. D. M.: Mevers. A. I. Chen. Rev 1982. 82. 223. (b) Kutney. J. P. Heteroctcles 1977. 7.593. (c) Lyle. R. E.: Abramovitch. R. A. Pridine and Its Derivatives. 1st ed.: Wiley-Interscience: New York. USA 1974: Part 1. p 137. (d) Eisner, U: Kuthan. J. Chem. Rev. 1972. 72 . 1. (e) Nicolas, B.: Hassan. H. F. J. Med. Chem. 1983. 26, 313. (f) Nicolas, B.: Hassan. H. F. J. Pham. Science 1983. 26. 313. (g) Nicolas. B.: Hassan. H. F. Science 1983. 26.313.

2. Nicolas. B.: Hassan. H. F.: Brewster. M. Science 1981. 2H. 1370. (b) Nicolas. B.: Brewster. M. Phamacol. Ther 1983. 19. 337. (c)
Nicolas. B.: James. W. S. J. Science 1983. 26.313

3. Kourounakis. A.: Nicolas. B.: Tames. W. S. J. International Joumat of Phomt 1996. 1+1. 239

4. (a) Piers, E.: Soucy, M. Con. J. Chem 1974, 52. 3563. (b) Aliba. K.: Isehi, Y.: Wada, M. Tetrahedron Lett. 1982. 23, 429. (c) Weller, D. D; Luellen. G. R.: Weller. D. L. J. Org. Chem 1983. 48. 3061 .

5. Reija. T.: Jari. M.: Mauri. L. Heterocycles 1991. 32. 511.

6. John. .T. The Chemical Smthesis of Peptides: Balliol college: Oxford, UK, 1991: Chap. 5,p 53

7. (a) Fraenkel, G: Cooper. J. W.: Fink. C. M. Angew. Chem. Iht Ed Engl. 1970, 9, 523 .

8. Fowler. F. W. J. Org Chent 1972.37. 1321

9. Emil. P.: Marcus. E. B.: Nicolas. B. Intemational Joumal of Outumt Chemistry: Oututum Biology Simpositum 1993. 20 . 17

10. Ray E. H. Jerry M. H. Anal Chem 1964, 36. 1813

11. Krishinamurthy. S.: Aimins, D. J. Org. Chem 1989, 54, 4458

12. Carl. D.: Grossmant. I. Contribution from the Deparment of Chentistry of wowne State Lninersity 1957. 79.2553.

13. Brown. H. C.: Weissman. P. M. J. Ant Chem. Soc. 1965. 87. 5614.

14. Brown. H. C. Weissman. P. M; Yoon. N. M. J. Am. Chem. Soc. $1966,88,1458$

15. Brown. H. C.: Yoon, N. M. J. Am. Chem. Soc. 1956. 88, 1464

16. Brow1. H. C.: Subba. R. B. J. Am. Chent Soc. 1956. 78.2582

17. (a) Brown. H. C.: Cha. J. S.: Nazer. B.: Kim. S. C.: Krishnamuthy. S.: Brown. C. A. J. Org Chen 1984. 49. 885. (b) Brown. H. C.: Nazer. B.: Cha, J. S. Synthesis 1984, 498. 